\title{
Occupational Safety Issues in Residential Construction Surveyed in Wisconsin, United States
}

\author{
Sang D. CHOI ${ }^{1,2 *}$ and Kathryn CARLSON ${ }^{1}$ \\ ${ }^{1}$ Department of Occupational and Environmental Safety and Health, Center for Occupational Safety and \\ Ergonomics Research, University of Wisconsin-Whitewater, USA \\ ${ }^{2}$ Department of Industrial and Systems Engineering, KAIST (Korea Advanced Institute of Science and \\ Technology), Republic of Korea
}

Received January 9, 2014 and accepted June 26, 2014

Published online in J-STAGE July 11, 2014

\begin{abstract}
Residential construction is a high-risk industry in the U.S. due to the exposure to workrelated safety hazards and fall injuries. This study aimed to examine the safety training and safe work practices of construction workers within the small residential construction industry. In order to achieve the study objectives, a survey was designed and sent to approximately 200 Wisconsin based residential construction contractors. About one third of the respondents stated that they did not have any form of safety programs. The study indicated that the most common types of workrelated injuries in residential construction were slips/trips/falls and cuts/lacerations. The survey findings also suggested that the residential construction contractors needed to increase the utilization of fall protection safety equipment. Further education and subject matter expert training could provide benefits to improve occupational safety and health of the small business workforce in the residential construction industry.
\end{abstract}

Key words: Small business, Occupational safety, Questionnaire, Residential, Construction

Residential construction is an important subsector in the United States construction industry, producing nearly half of the value of private construction in the nation ${ }^{1)}$. Particularly for those employed in residential construction, falls from heights remain the leading cause of work-related injuries and fatalities among construction workers, despite the overall declining trend in injury rates in the United States $^{2,3)}$. There are many factors affecting fall risks and hazards present on different types of construction sites. Significant variations exist between building materials, construction methods, equipment, safety monitoring, and work organization between residential and nonresidential construction $^{4}$. In general, larger commercial construction

*To whom correspondence should be addressed.

E-mail: chois@uww.edu

(C)2014 National Institute of Occupational Safety and Health companies are generally better organized from a safety standpoint than smaller residential companies ${ }^{5,6)}$. Work crews in residential construction are often much smaller than in commercial construction, in which workers may be less specialized and have less experience with a particular $\operatorname{task}^{7)}$. Due to the fast-paced nature of residential construction and concerns regarding productivity, addressing fall safety in residential construction is a challenging endeavor $^{7-9)}$. The U.S. National Institute for Occupational Safety and Health (NIOSH) and the U.S. Occupational Safety and Health Administration (OSHA) have recognized residential construction as a dangerous industry, due to the hazards employees face while working at heights ${ }^{10)}$. Fatalities in the residential construction industry can potentially happen for many reasons ranging from individuals not having proper personal protective equipment to lack of training on the hazards. Falls from height remain 
the most common cause of workplace fatalities among residential construction workers, accounting for $64 \%$ of the fatalities in residential building and $100 \%$ of the fatalities among framing contractors ${ }^{11)}$. Specifically with small companies in the construction industry there is a lack of information on hazard recognition, which has been a focus for NIOSH when they published small business safety \& health resource guide. A company involved in the residential construction industry can experience falls from the following areas: the roof, from a ladder, from scaffolding or staging, through floor openings, and other unknown types of falls ${ }^{12)}$. Despite the higher risk of fatalities among the residential construction industry, studies on small businesses, those with less than 10 employees, in this subsector are very scarce. Due to the nature of residential construction work and significant differences between small and large businesses, studies covering safety components and fall hazards in large businesses may not yield results with applicable strategies for reducing fatalities among residential workers. The purpose of this survey study was to investigate residential construction company owners and/or residential construction workers to find out if they are incorporating safe work practices in their operations.

To achieve the study objectives, the researchers first studied injury and illness trends of the residential construction industry. The information studied was found in many sources including books, electronic copies of books, scholarly journals articles, and web sites. After the literature review was completed, a draft survey questionnaire was developed and distributed to a residential construction company owner for review. The draft survey was distributed and administered through email to two small residential construction companies in Wisconsin. This was assured through the owner of the company, based on employment for the past year. The greatest improvement made through the draft survey review was to update the format of the survey to make it clearer and organized at first glance. Also the researchers added more constructing equipment and safety equipment commonly used in residential construction. After the review, the final two-page survey questionnaire was developed (Appendix 1). The target audience of the survey was residential construction workers or owners of small businesses in Wisconsin in order to describe the current status of the safety training and safe work practices among this sector. For this study's purpose "residential construction company" is a Wisconsin based company engaged in residential construction as interpreted by OSHA. The Occupational Safety and Health Administration's (OSHA) interpretation of residential construction combines two elements: (1) the end-use of the structure being built must be as a home (i.e., a dwelling), and (2) the structure being built must be constructed using traditional wood frame construction materials and methods ${ }^{13)}$. Distribution methodology involved postal mailing the survey to companies and having them filled out by either an owner or worker. The questionnaire respondents had very extensive knowledge and fieldwork experiences in residential construction as often in small companies owners were the constructors. A total of 21 residential construction contractors completed the survey.

The participants represented companies that have been in business from 5 to $50 \mathrm{yr}$ with an average of $24 \mathrm{yr}$ in the residential construction business. The companies represented in the survey employed average approximately 4 employees (ranging 1 to 12 employees) in residential construction. Ninety percent (19 of 21 respondents) were male, while $10 \%$ ( 2 of 21 ) were female. Ninety five percent ( 20 of 21 ) were white and $5 \%$ were Hispanic. The type of work performed was reported as residential construction, roofing, carpentry, masonry, siding, installing windows, drywall, cabinetry, and remodeling.

Participants of the survey indicated that 67\% (14 of 21 firms) have verbal or written safety programs in place, while 33\% ( 7 of 21 ) did not have any form of safety programs. As shown in Fig. 1, the most common types of safety training programs included equipment safety $(16 \%$ (13 of 80 total cases)), fall protection $(15 \%(12 / 80))$, ladder safety $(15 \%(12 / 80))$, scaffolding (14\% (11/80), first aid $(13 \%(10 / 80))$, forklift $(9 \%(7 / 80))$, emergency preparedness $(8 \%(6 / 80))$, hazard communication $(6 \%(5 / 80))$, and crane $(5 \%(4 / 80))$. As the questionnaire allowed checking multiple answers, the number of total cases was the sum of all the applicable cases selected by the survey participants.

The most common form of safety communication/training was to convey the information verbally/lecture (39\% (13 of 33 total cases)), followed by on-the-job communication or training $(30 \%(10 / 33))$, meetings $(15 \%(5 / 33))$, videos $(9 \%(3 / 33))$, and books/brochures $(6 \%(2 / 33))$ (Fig. 2). The number of total cases was the sum of all the applicable answers selected by the survey participants.

However, twenty-nine percent (6 of 21 respondents) were "unsure" of how often the firms communicate safety to their employees, while another $29 \%(6 / 21)$ described their communication regarding safety as weekly, followed by daily $(19 \%(4 / 21))$, monthly $(14 \%(3 / 21)$, and annually $(10 \%(2 / 21))$ (Fig. 3).

This survey data can provide information in regards to 


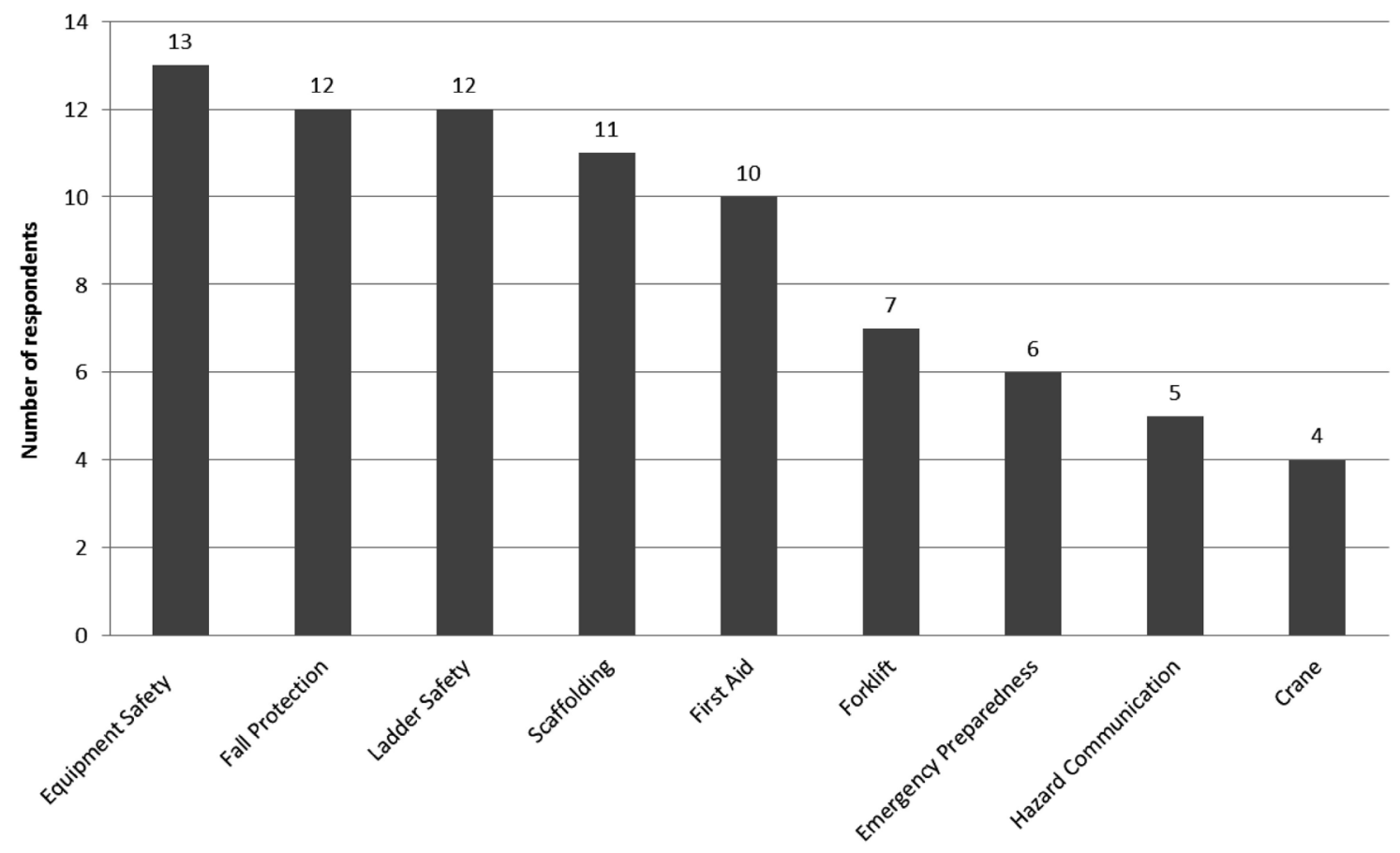

Fig. 1. Safety programs-survey results.

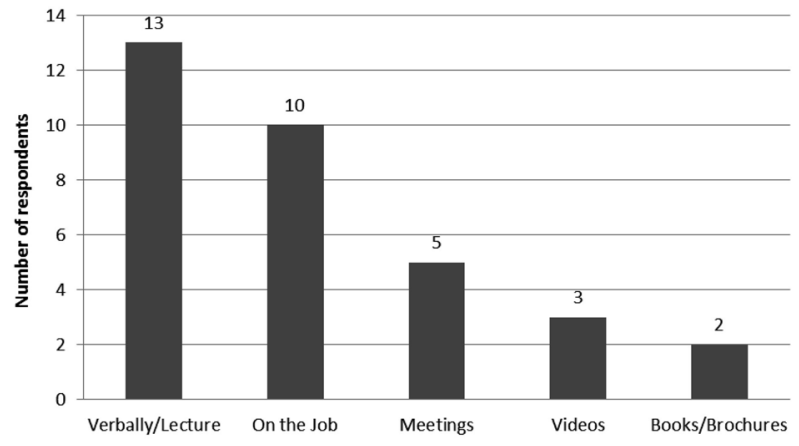

Fig. 2. Method of safety training provided to employees-survey results.

the ways safety is distributed among small workforces, if the workforce is diverse, and what components are primary among a high-risk industry. The data presented by participants indicates that the sample of workers were predominately white ( $95 \%$ or 20 of 21 respondents), training/ communication was presented in one language - English (only 1 of 21 respondents stated that they provide training in another language, Spanish), and was most commonly communicated on a weekly basis.

Participants were asked about the kind of equipment they use for residential construction with options of hand tools, power tools, scaffolding, crane, front end loader, forklift, ladders, jack hammers, gas powered equipment,

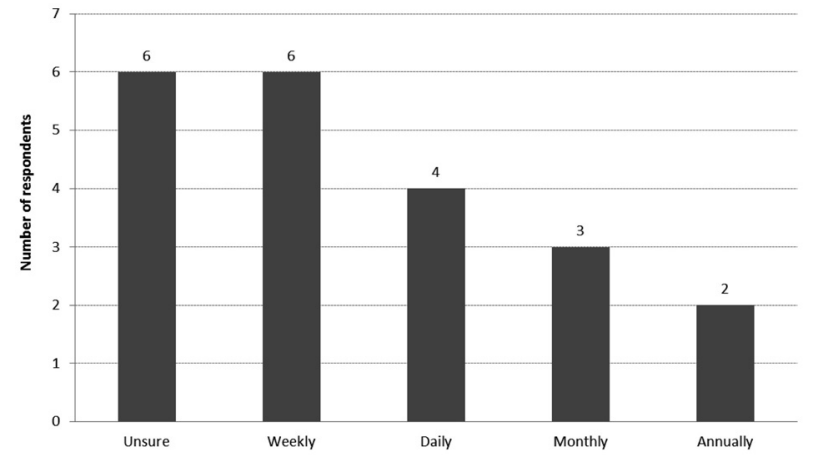

Fig. 3. Frequency of safety training-survey results.

air powered equipment or other. The main types of equipment used in the residential construction workplace were hand tools (15\% (20 of 136 total cases)) and power tools (15\% (20/136)), followed by ladders (14\% (19/136)), scaffolding (13\% (17/136), air powered equipment (12\% $(16 / 136))$, gas powered equipment $(11 \%(15 / 136)$, forklift (7\% (9/136), crane $(6 \%(8 / 136)$, jack hammer $(4 \%$ (6/136), and front end loader (4\% (6/136)) (Fig. 4). As the questionnaire allowed checking multiple answers, the number of total cases was the sum of all the applicable cases selected by the survey participants.

Participants were also asked what types of safety equipment they currently use. The most common types of safety 


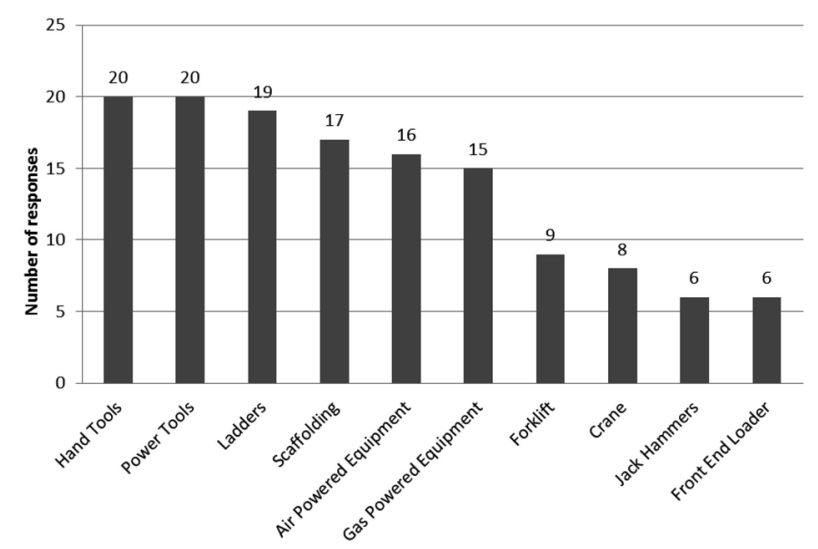

Fig. 4. Type of equipment used in residential construction-survey results.

equipment used by the participants were safety glasses (18\% (19 of 105 total cases)) followed by gloves (17\% $(18 / 105))$, hearing protection $(16 \%(17 / 105))$, safety shoes $(11 \%(12 / 105))$, fall protection $(11 \%(12 / 105))$, dust masks $(10 \%(11 / 105))$, hard hats $(9 \%(9 / 105)$, and back support $(7 \%$ (7/105)) (Fig. 5). As the questionnaire allowed checking multiple answers, the number of total cases was the sum of all the applicable cases selected by the survey participants.

The participants were also asked questions regarding injury and illness data. The participants reported that none of the companies represented by the data have experienced fatalities on their jobsite. The most common types of injuries reported by the survey participants were slip/trip/ fall (36\% (14 of 39 total cases) followed by cuts/lacerations $(33 \%(13 / 39)$, injuries from hand tools $(13 \%(5 / 39))$, overexertion ( $8 \%(3 / 39))$, struck by $(8 \%(3 / 39))$ and injury involving powered equipment (3\% (1/39)) (Fig. 6). As the questionnaire allowed checking multiple answers, the number of total cases was the sum of all the applicable cases selected by the participants.

The next question asked what the most common type of falls the participant has experienced. The options were fall to the same level or fall to lower height. Five participants responded that the most common type of fall they have experienced was a fall to the same level, and five participants responded that the most common fall they have experienced was a fall to a lower level from between 4-15 feet. Only 2 participants that had experienced falls reported that they were wearing fall protection at the time of the fall. Lastly, participants were asked to rate their overall level of safety. Overall, $57 \%$ (12 of 21 respondents) rated their company as safe, $38 \%$ ( 8 of 21 ) rated their company as very safe, and 5\% rated their company as neither safe nor unsafe.

This survey study examined the safety training and safe work practices of construction workers within the small residential construction industry in Wisconsin. Although the residential construction contractors seemed informed on the safety hazards in general, approximately one third of the participants in the survey indicated that they did not have any verbal or written safety programs. Most of the safety training was delivered through verbal/lecture or onthe-job site training in regards to the equipment safety, fall protection, and ladder safety. The common types of equipment used in residential construction were power/ hand tools and ladders/scaffolding, and the common injuries were associated with slips/trips/falls and cuts/lacerations. Majority of the residential contractors or workers participated in this study were protecting themselves with personal protective equipment (PPE) of safety glasses, gloves, and hearing protection.

The fall injuries are consistent with information that OSHA published specifying that falls are the leading cause of death for workers engaged in residential construction ${ }^{13)}$. It is interesting to note that while 80 percent of companies responded that they work from heights whether by ladder or scaffolding only 51 percent of companies stated that they use fall protection as part of their safety equipment. This could be the result of lack of knowledge of fall protection equipment/systems or how to use appropriate fall protection to address hazards. OSHA's Guidance Document for Residential Construction outlines technologies to provide conventional fall protection during home construction $^{13)}$. In this document several types of fall protection are addressed - guardrails, personal fall arrest systems and safety nets. The falls found in this study are mostly consistent with the Bureau of Labor Statistics (BLS) data regarding the most common types of falls - from a ladder, roof, and scaffolding. With regard to the residential specialty trade sector, $80 \%$ of fatalities in the residential roofing industry were from falls. Among fall decedents in residential construction, nearly one in three was selfemployed. In addition, workers who were aged 55 and older, were foreign-born Hispanic, or worked for small establishments (1-10 employees), had higher proportions of fatal falls in residential construction compared to those in nonresidential construction. Residential and nonresidential construction also varied by fatal fall type. Falls from roofs and ladders accounted for a larger proportion of fatal injuries in residential construction, whereas nonresidential construction had a higher proportion of falls 


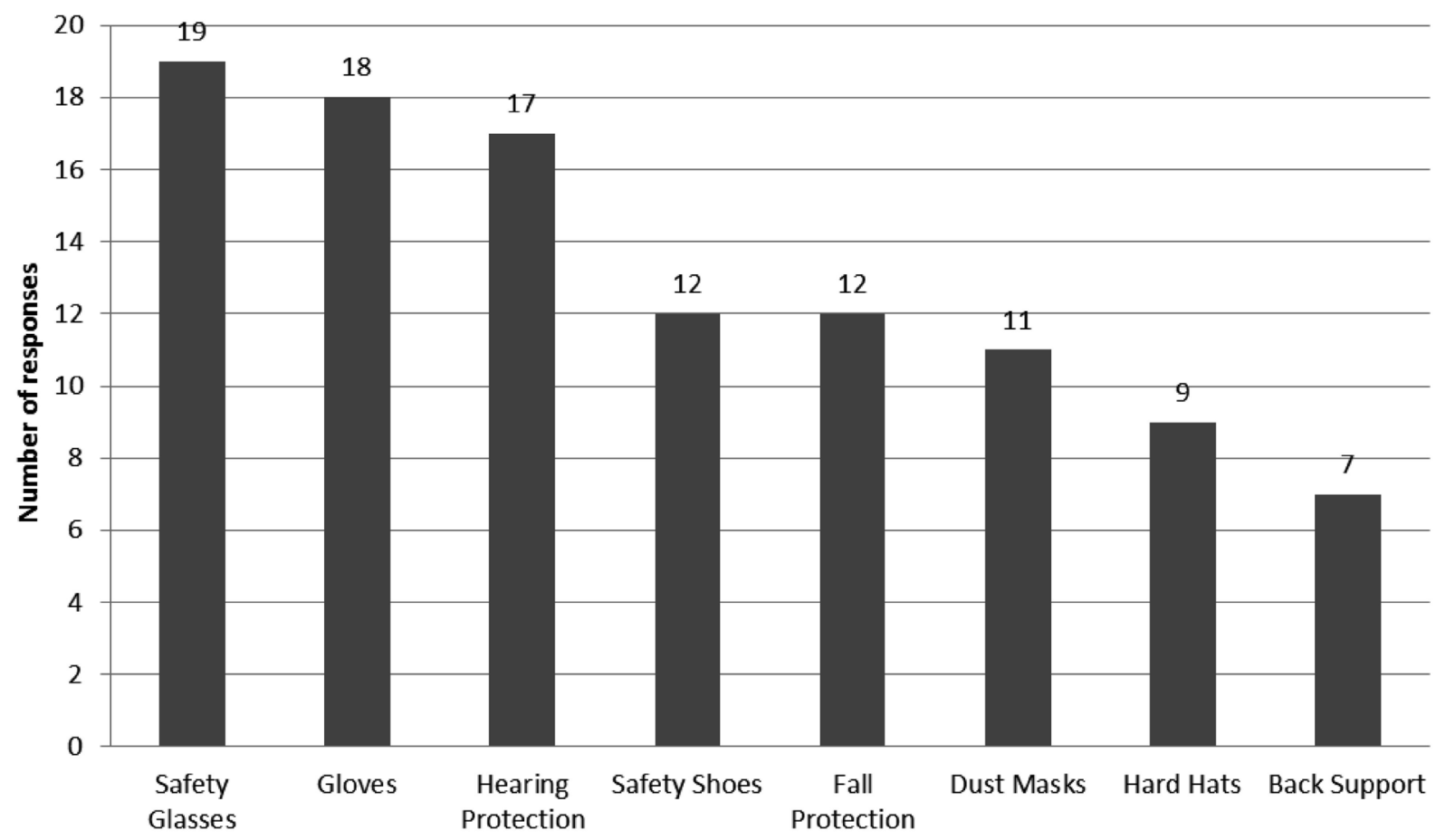

Fig. 5. Safety equipment used in residential construction-survey results.

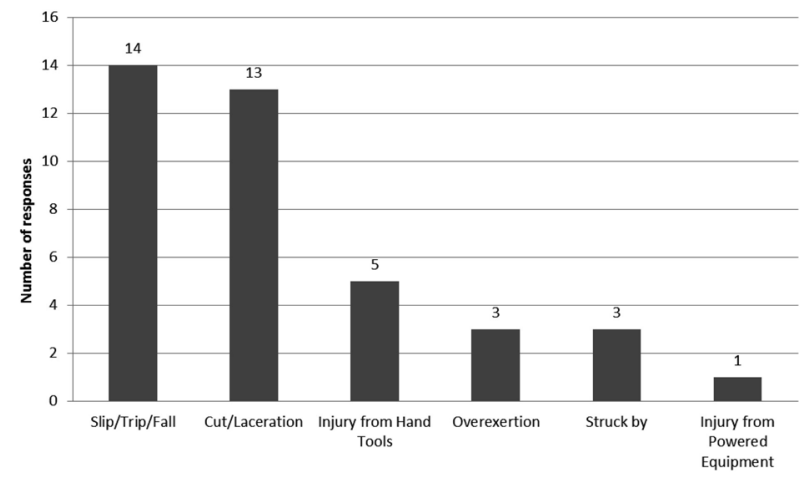

Fig. 6. Type of injuries experienced in residential constructionsurvey results.

from nonmoving vehicles and from building girders or other structural steel ${ }^{14)}$. Also, a larger amount of fatal falls in residential construction occurred while constructing/ repairing/ cleaning, climbing/descending, and from painting when compared to non-residential construction.

Of the companies that responded the awareness regarding the importance of safety seemed to be prominent in their operations. The use of some type of PPE was evident by over half of the participants, but it seemed a large population that was still not using proper protection when faced with high risk hazards such as falls. It should be noted here that a substantial gap existed where majority of residential contractors work from heights, yet only small portion of residential construction companies used the fall protection system. Education and subject matter expert training could provide great benefits to this sector. For instance, OSHA's website had a wide variety of educational and training materials to assist employers of all sizes with compliance (e.g., multiple easy-to-read fact sheets, PowerPoint and slide presentations, as well as other educational materials were available on the fall protection in residential construction $)^{15,16)}$. Education and training in multiple languages would also provide information to alleviate the injuries and fatalities among the self-employed and small business workforce in the residential construction industry. It should be noted that the results of the present study might be different from the other parts of the country when the survey is limited to one region. In the future, the authors plan to survey a larger sampling of residential construction contractors in an effort to develop a national database. All in all, the findings of this study could still provide helpful direction and insights into safe work practices to improve occupational safety and health in the residential construction sector. 


\section{References}

1) U.S. Census BureauAnnual Value of Construction Put in Place 2002-2012. Economic Census. http://www.census. gov/construction/c30/pdf/total.pdf. Accessed July 15, 2013.

2) CPWR - The Center for Construction Research and Training (2013) The construction chart book: The U.S. construction industry and its workers: 5 th edition. Silver Spring, CPWR.

3) Dong XS, Choi SD, Borchardt JG, Wang X, Largay JA (2013) Fatal falls from roofs among U.S. construction workers. J Safety Res 44, 17-24. [Medline] [CrossRef]

4) Choi SD (2007) Opportunities for improving productivity in roofing construction. Int J Constr Educ Res 3, 67-77. [CrossRef]

5) Choi SD (2006) A survey of the safety roles and costs of injuries in the roofing contracting industry. J Saf. Health Environ Res 3, 1-20.

6) Sa J, Seo DC, Choi SD (2009) Comparison of risk factors for falls from height between commercial and residential roofers. J Safety Res 40, 1-6. [Medline] [CrossRef]

7) Kaskutas V, Dale AM, Lipscomb H, Gaal J, Fuchs M Evanoff B, Carpenters' Joint Apprenticeship Program Instructor Team (2010) Changes in fall prevention training for apprentice carpenters based on a comprehensive needs assessment. J Safety Res 41, 221-7. [Medline] [CrossRef]

8) Lipscomb HJ, Dale AM, Kaskutas V, Sherman-Voellinger R, Evanoff B (2008) Challenges in residential fall prevention: insight from apprentice carpenters. Am J Ind Med 51, 60-8.
[Medline] [CrossRef]

9) Kaskutas V, Evanoff B, Miller H (2013) Fall prevention on residential construction sites. Prof Saf 58, 36-40.

10) U.S. National Institute for Occupational Safety and Health (1999) Identifying High-Risk Small Business Industries. DHHS (NIOSH) Publication No. 99-107.

11) U.S. Bureau of Labor Statistics (BLS) Census of fatal occupational injuries: current and revised data. U.S. Department of Labor. http://www.bls.gov/iif/home.htm. Accessed September 24, 2013.

12) U.S. Bureau of Labor Statistics (BLS) Incidence rates of nonfatal occupational injuries and illnesses by industry and case types, U.S. Department of Labor. http://www.bls.gov/ iif/home.htm. Accessed November 8, 2013.

13) U.S. Occupational Safety and Health Administration (OSHA) Residential construction industry. U.S. Department of Labor. http://www.osha.gov/SLTC/residential/index. html. Accessed October 16, 2014.

14) Dong XS, Wang X, Largay JA, Platner JW, Stafford E, Cain CT, Choi SD (2014) Fatal falls in the U.S. residential construction industry. Am J Ind Med 57, 992-1000 [CrossRef]. [Medline]

15) Smith S (2012) Efforts to reduce injuries and fatalities in residential construction extended by OSHA. EHS Today.

16) U.S. Occupational Safety and Health Administration (OSHA) Fall protection in residential construction. https:// www.osha.gov/doc/topics/residentialprotection/index.html Accessed January 8, 2014. 


\title{
Appendix 1. Survey Instrument
}

\author{
Background \\ Gender: $\quad \square$ Male $\quad \square$ Female \\ What is your race? $\square$ Black $\square$ Hispanic $\square$ White $\square$ Asian/Pacific Islander $\square$ Other \\ Location (State): \\ Your work experience in residential construction: Year(s) ___ Month(s) \\ What type of work do you do? \\ How many employees including you are in your company? \\ Employees
}

\section{Safety programs}

Does your company have safety programs (written or verbal)? $\quad \square$ Yes $\quad \square$ No $\quad \square$ Unsure

a. If 'Yes' which one(s) have you received training on? (Please Check all that apply)

$\square$ Fall Protection $\square$ Hazard Communication $\square$ First Aid $\square$ Emergency Preparedness $\square$ Forklift

$\square$ Crane $\square$ Ladder Safety $\quad \square$ Scaffolding Equipment Safety $\square$ Other:

b. How long has your company's safety programs been implemented?

Does your company provide safety communication/training? $\square$ Yes $\square$ No $\square$ Unsure

c. If 'Yes', how is safety communicated to employees? (Check all that apply)

$\square$ Verbally/Lecture $\square$ Videos $\square$ On the job $\square$ Meetings $\square$ Web Based $\square$ Books/Brochures

d. If 'Yes', how often does your company communicate with its employees regarding safety?

Every __ day(s) Every _ week(s) Every _ _ month(s) Every __ year(s) $\square$ Unsure

e. If 'Yes', does your company offer communication in multiple languages? $\square$ Yes $\square$ No

f. If 'Yes', Check all that apply: $\quad \square$ English $\quad \square$ Spanish $\quad \square$ Hmong $\quad \square$ French $\quad \square$ German $\square$ Other:

What kind of equipment do you use for residential construction? (Check all that apply)

$\square$ Hand tools $\quad \square$ Power Tools $\square$ Scaffolding $\square$ Crane $\quad \square$ Front End Loader $\quad \square$ Forklift

$\square$ Ladders $\square$ Jack Hammers $\square$ Gas powered equipment $\square$ Air Powered Equipment $\square$ Other:

What kind of safety equipment do you currently use? (Check all that apply)

$\square$ Gloves $\square$ Safety Glasses $\square$ Safety Shoes $\square$ Back Support $\square$ Hard Hats $\square$ Hearing Protection

$\square$ Dust Masks $\square$ Fall Protection $\square$ Other:

Injuries and illnesses

Has your company ever had a fatality or death at the jobsite? $\square$ Yes $\square$ No

Have you ever had injuries at the jobsite? $\square$ Yes $\square$ No

What has caused the injuries? (Please Check all that apply)

$\square$ Overexertion $\quad \square$ Cut/Laceration $\quad \square$ Fall $\square$ Slip $\quad \square$ Trip $\quad \square$ Hand tools $\quad \square$ Powered Equipment

$\square$ Electrocution $\quad \square$ S truck By (object or machine) $\square$ Caught in/between $\square$ Other

Have you ever experienced fall injuries at your worksite? $\square$ Yes $\square$ No

a. If 'Yes', what types of falls occurred? (Please check all applicable)

$\square$ Falls from roofs $\square$ Falls from ladders $\square$ Falls from scaffolds $\square$ Other

What are the most common types of falls that you have experienced?

$\square$ Fall to same level $\square$ Fall to lower level (Height of fall ___ feet)

b. Did you wear or install fall protection devices at those times? $\square$ Yes $\square$ No

If yes, what caused the falls?

$\square$ Incomplete connection of personal fall arrest system

$\square$ Improper use of fall protection devices

$\square$ Out of date fall protection devices

$\square$ Other (please explain)

How would you rate the overall level of safety of your worksite?

$\square$ Very unsafe $\square$ Unsafe $\square$ Neither safe nor unsafe $\square$ Safe $\quad \square$ Very safe 